\title{
Retroperitoneal Inflammatory Myofibroblastic Tumor: A Rare Case Report and Literature Review
} Retroperitoneal Inflamatuvar Miyofibroblastik Tümör: Olgu Sunumu ve Literatür Taraması

\author{
Oktay Üçer MD1, Mehmet Yüksel MD1, Gökhan Temeltaş MD1, Peyker Temiz MD2, Talha Müezzinoğlu MD1 \\ ${ }^{1}$ Celal Bayar University, Faculty of Medicine, Department of Urology, Manisa, Turkey \\ ${ }^{2}$ Celal Bayar University Faculty of Medicine, Department of Pathology, Manisa, Turkey
}

\begin{abstract}
Summary
Primary retroperitoneal inflammatory myofibroblastic tumors (IMT) are a very rare clinical condition. Herein, we present a case of IMT in the retroperitoneal area. A 52-year-old woman presented with abdominal lump and exhaustion. On physical examination, there was no pathological finding. The diagnostic workup included contrast computer tomography that revealed a $10,5-\mathrm{cm}$ heterogeneous retroperitoneal mass under the right adrenal gland, localized behind the right kidney. At laparotomy, the mass arising from the retroperitoneum was excised. Histopathology showed an IMT. IMTs has a variable biologic behavior that ranges from the frequently benign lesions to more aggressive variants. Final diagnosis is based on histomorphological features. Complete surgical excision should be the aim of the curative treatment. Keywords: Retroperitoneum, myofibroblastic tumor, inflammatory myofibroblastic tumor
\end{abstract}

Öz

Primer retroperitoneal inflamatuvar miyofibroblastik tümörler (IMT) klinikte oldukça nadir görülür. Burada retroperitoneal alandaki IMT olgusu sunuldu. Elli iki yaşında kadın hasta batında kitle ve halsizlik şikayetleriyle başvurdu. Fizik muayenesinde patolojik bir bulgu saptanmadı. Kontrastlı bilgisayarlı tomografisinde retroperitonda sağ adrenal bezin altında ve böbreğin arkasında 10,5 cm çaplı heterojen kitle görüldü. Kitle cerrahi olarak eksize edildi ve patolojisi IMT geldi. IMT kötü huylu lezyonlardan daha agresif özellikler taşıyana kadar değişik şekillerde görülebilmektedir. Kesin tanı histopatolojik olarak konulmaktadır. Küratif tedavideki amaç kitlenin tam cerrahi eksizyonudur.

Anahtar Kelimeler: Retroperiton, miyofibroblastik tümör, inflamatuvar miyofibroblastik tümör

\section{Introduction}

The inflammatory myofibroblastic tumor (IMT), also known as inflammatory pseudotumor, is an uncommon tumor characterized by a controversial etiology, various histopathological features, and an unpredictable biological behavior (1). The profile of this disease has changed with time from benign reactive process to a malignant neoplasm, based on the multiple case reports demonstrating recurrent and constant clonal genetic alterations (2). There are three main histological patterns; nodular fasciitislike, fibrous histiocytoma-like, and desmoid or scar tissue-type (3). IMT is usually diagnosed in adults in the lungs. It is also described in the other locations, such as the kidney, orbit, liver, pancreas, spleen mesentery and limbs and may also be seen during childhood (4). However, retroperitoneal location is rarely reported in literature.

\section{Case Report}

The patient is a 52-year old woman with a history of abdominal lump and complaint of exhaustion for two years, and with no history of urinary tract symptoms. She had no history of abdominal trauma, or urinary tract infection, but she underwnt umbilical hernia repair 5 years ago. Physical examination did not reveal any pathological findings. Blood count parameters were within normal limits except low hemoglobin rate (hemoglobin: 11.7). C-reactive protein and tumor markers were also negative. Contrast-enhanced computed tomography revealed an $84 \times 78 \times 106 \mathrm{~mm}$ mass on the right side, located inferior to the adrenal gland, and posterior to the kidney (Figure 1). It seemed to be separate from the kidney tissue. Tru-cut biopsy was performed; Histopathological examination revealed connective tissue infiltrated by $\mathrm{T}$ and $\mathrm{B}$ lymphocytes and enlarged vascular structures. There were no tumor cells seen 
in the biopsy material. After multidisciplinary discussion, an exploratory laparotomy was decided. During the surgery, the solid mass was totally excised and frozen section analysis of the right renal parenchyma showed clean surgical borders without any malignant cells. Postoperative pathologic examination was consistent with IMT (Figure 2). No medical therapy was needed after surgery. There was no sign of recurrence and the patient remained asymptomatic for 6 months after the surgery. The patient provided written consent for the use of her information in this case report.

\section{Discussion}

IMT is a subtype of inflammatory pseudotumor that is characterized by a proliferation of cells presenting a myofibroblastic differentiation. It is a rare lesion that has been reported with an equal frequency in men and women. It can occur at any age but most often before the age of 40 (5). Originally described in the lungs in 1937, and since then, it has been reported to occur throughout the body including the mesentery, stomach, abdomen, liver, mediastinum, omentum and bladder of children and adolescents (6). Retroperitoneal IMT's are extremely rare. This tumor was previously described as an inflammatory pseudotumor, inflammatory

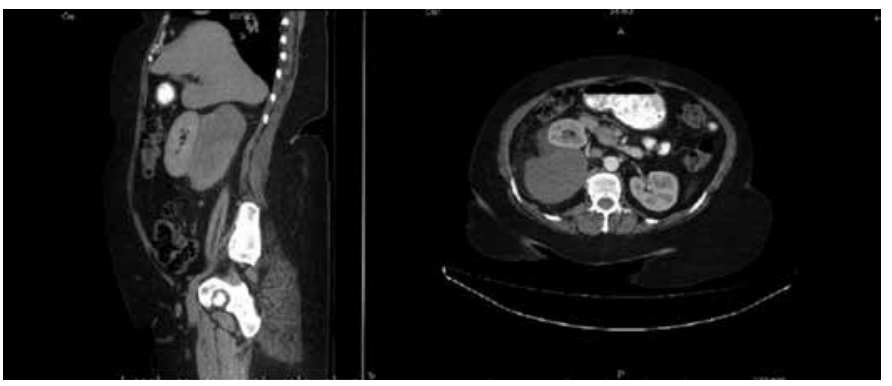

Figure 1. The view of retroperitoneal inflammatory myofibroblastic tumor in the contrast computed tomography

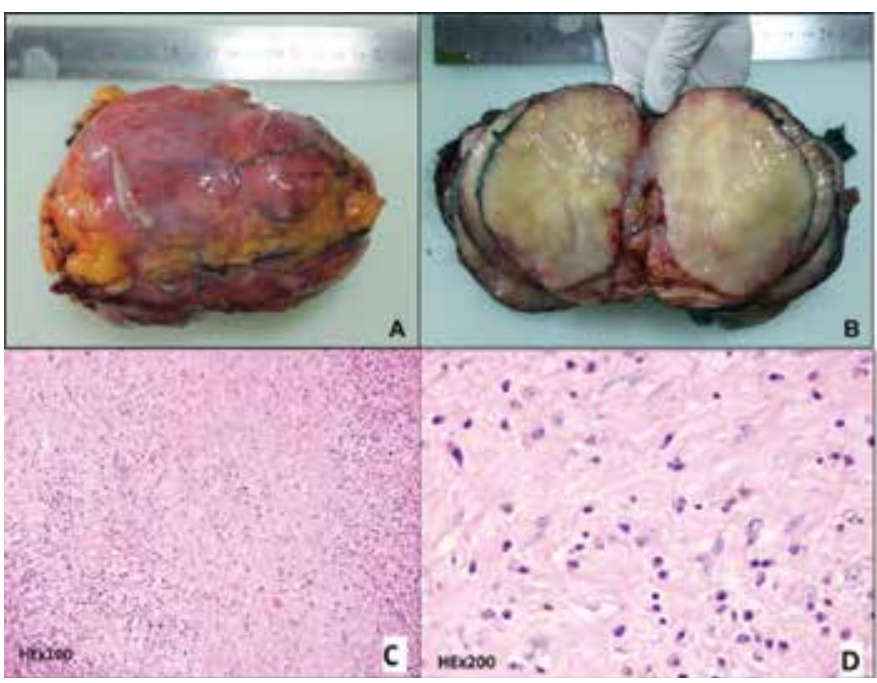

Figure 2. Macroscopic $a, b)$ appearances of the mass after surgical removal, c) Inflammatory cells entwined with collagenized tumor areas $(\mathrm{HE}, \times 100)$, d) Inflammatory component in tumor and fibroblastic cell without atypia (HE, x200) myofibroblastoma, lymphoplasmacytic, histiocytoma, and fibrous pseudotumor until 1994 when myofibroblastic tumor was established as a distinct low grade malignancy by the World Health Organization classification (7).

The etiopathology of IMT is actually controversial and is still not completely known. Trauma, surgery, inflammation, viral (Epstein-Barr Virus or Human Herpes Virus) and bacterial (Actinomyces, C. Jejuni or E. Coli) infections may affect the development of IMT (5). More recent studies have found cytogenetic clonality, 2p23 chromosomal region involvement, and occasional aggressive local behavior, along with tumor metastasis suggesting IMT's to be neoplasms (8).

The clinical presentation of the tumor often depends on its anatomical site. Retroperitoneal tumors usually grow slowly and always present as a solid abdominal palpable mass. Flank or abdominal pain usually exists. Systemic symptoms such as fever, weight loss and laboratory abnormalities (hypochromic microcytic anemia and raised erythrocyte sedimentation rate); hematuria is also reported (1).

Radiologically, the findings are nonspecific and only reveal a solid well defined mass. Surgical resection could be the preferred in the treatment of IMT, which can also be used to confirm this disease. The recurrence rate has been reported to range from $18 \%$ to $40 \%$, and only precise removal of the tumor will avoid recurrence. In patients with unresectable IMT's; Nonsteroidal anti-inflammatory drugs (NSAID) and chemotherapeutic agents will be successfully used. Therefore chemotherapy combined with oral NSAIDs may also be a feasible therapeutic choice in patients with unresectable retroperitoneal IMT (6). In this case, we performed a total surgical resection of the retroperitoneal IMT, and no recurrence during the 6 months follow up.

\section{Conclusion}

IMT are true neoplasms of proliferating myofibroblasts with an associated inflammatory component. They have a variable biologic behavior that ranges from the frequently benign lesions to more aggressive variants. Final diagnosis is based on histomorphological features. Due to their rarity, there are no well-defined protocols for the treatment especially in cases of malignant behavior. Complete surgical excision should be the aim of the curative treatment. Long term clinical, radiological and laboratory follow-up is indicated because of the potential for local recurrence even after many years.

\section{Ethics}

Informed Consent: Consent form was filled out by the patient. Peer-review: Internal peer-reviewed.

\section{Authorship Contributions}

Surgical and Medical Practices: Oktay Üçer, Gökhan Temeltaş, Concept: Oktay Üçer, Mehmet Yüksel, Design: Oktay Üçer, Data Collection or Processing: Oktay Üçer, Gökhan Temeltaş, Analysis or Interpretation: Peyker Temiz, Literature Search: Oktay Üçer, Talha Müezzinoğlu, Writing: Oktay Üçer.

Conflict of Interest: No conflict of interest was declared by the authors.

Financial Disclosure: The authors declared that this study has received no financial support. 


\section{References}

1. Coffin CM, Watterson J, Priest JR, Dehner LP. Extrapulmonary inflammatory myofibroblastictumor (inflammatory pseudotumor). A clinicopathologic and immunohistochemical study of 84 cases. Am J Surg Pathol 1995;19:859-872.

2. Pungpapong S, Geiger XJ, Raimondo M. Inflammatory myofibroblastic tumor presenting as a pancreatic mass: A case report and review of the literature. JOP 2004;5:360-367.

3. Attili SV, Chandra CR, Hemant DK, et al. Retroperitoneal inflammatory myofibroblastic tumor. World J Surg Oncol 2005;3:66.
4. Poves $\mathrm{I}$, Alonso $\mathrm{S}$, Jimeno $\mathrm{M}$, et al. Retroperitoneal inflammatory pseudotumor presenting as a pancreatic mass. JOP 2012;13:308-311.

5. Ziadi S, Trimeche M, Mestiri S, et al. Retroperitoneal inflammatory myofibroblastic tumor: Case report and immunohistochemistry study. World J Oncol 2010;1:94-96.

6. Tao YL, Wang ZJ, Han JG, Wei P. Inflammatory myofibroblastic tumor successfully treated with chemotherapy and nonsteroidals: A case report. World J Gastroenterol 2012;18:7100-7103.

7. Bahadori M, Liebow AA. Plasma cell granulomas of the lung. Cancer 1973;31:191-208.

8. Koirala R, Shakya VC, Agrawal CS, et al. Retroperitoneal inflammatory myofibroblastic tumor. Am J Surg 2010;199:17-19. 